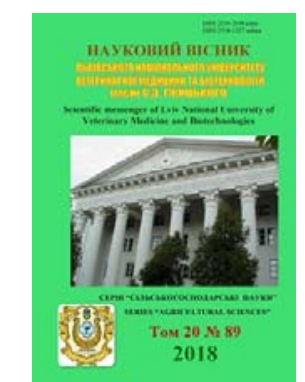

Науковий вісник Львівського національного університету ветеринарної медицини та біотехнологій імені С.3. Гжицького

\author{
Scientific Messenger of Lviv National University \\ of Veterinary Medicine and Biotechnologies
}

ISSN 2519-2698 print

ISSN 2518-1327 online doi: $10.32718 /$ nvlvet8909 http://nvlvet.com.ua/

UDC 363.32/38:612.015.3:636.084.4

\title{
The content and composition of the longissimus muscle proteins in the lambs of different ages under the intensive fattening
}

\author{
V.V. Havryliak ${ }^{1,2}$, P.V. Stapay ${ }^{2}$, V.M. Tkachuk ${ }^{3}$ \\ ${ }^{1}$ Lviv Polytechnic National University, Lviv, Ukraine \\ ${ }^{2}$ Institute of Animal Biology of NAAS, Lviv, Ukraine \\ ${ }^{3}$ Institute of Agriculture of Carpathian region NAAS, v. Obroshyno, Ukraine \\ Article info \\ Received 05.09.2018 \\ Received in revised form \\ 05.10 .2018 \\ Accepted 08.10.2018 \\ Lviv Polytechnic National \\ University, 3/4 sq. St. Yura \\ Lviv, 79013, Ukraine. \\ E-mail:havvita@ukr.net \\ Institute of Animal Biology \\ of NAAS, V. Stus Str., 38, \\ Lviv, 79034, Ukraine. \\ Institute of Agriculture \\ of Carpathian region NAAS, \\ Hrushevskyi Str., 5, v. Obroshyno, \\ 81115, Ukraine. \\ Tel: $+38-063-457-94-48$ \\ E-mail:vitalii-tkachuk@ukr.net \\ Havryliak, V.V., Stapay, P.V., \& Tkachuk, V.M. (2018). The content and composition of the \\ longissimus muscle proteins in the lambs of different ages under the intensive fattening. Scientific \\ Messenger of Lviv National University of Veterinary Medicine and Biotechnologies, 20(89), 52-55. \\ doi: $10.32718 /$ nvlvet8909 \\ The article presents data on the effect of intensive fattening of lambs on its weight gain, the chem- \\ ical and protein composition of the longissimus muscle tissue, the biological and nutritional value of \\ meat. For the experiments, the lambs of an Ascanian thin wool breed, Tauride type were used. Ac- \\ cording to the analog method, 12 newborn lambs with an average body weight of $4.58 \mathrm{~kg}$ were select- \\ ed, the suckling period in animals lasted 1.5 months. After 1.5 months of age, the animals were trans- \\ ferred to intensive fattening. It has been shown that during the suckling period the average weight of \\ lambs was $12.3 \mathrm{~kg}$, the average live weight gain - $7.8 \mathrm{~kg}$, and the overall daily live weight gain- \\ $172.1 \mathrm{~g}$. Intensive fattening contributed to the increase of the average daily gain to $215.0 \mathrm{~g}$ in \\ 4-month-old age lambs and up to $228.2 \mathrm{~g}$ - in the 5-month-old young sheep, respectively on 24.8 and \\ $32.5 \%$ more than in the 1.5-month-old animals. In the 4-month-old age lambs, the tissues of the \\ longissimus muscle contain a lower amount of dry matter (1.08\%) and total fat (1.74\%), on the same \\ time the higher content of total and soluble proteins, respectively 1.1 and 1.05 times, compared to the \\ 5-month old animals. It was found that the largest part of soluble proteins of the muscle tissue was in \\ the band of albumin mobility, smaller - all fractions of globulins and least-prealbumin both in the \\ 4th and 5th month of age of the animals. The higher content of soluble proteins in the longissimus \\ muscle of the lambs of the 4th month of age is due to the $\beta$ - and $\gamma$-globulin fractions, whereas in the \\ muscle of lambs of 5 months of age there is a higher content of the fraction of prealbumin and albu- \\ mins. Consequently, the biological and nutritional value of lamb meat of 4 months of age is better \\ than that of 5-month-old animals.
}

Key words: lambs, feeding, longissimus muscle, proteins, chemical content.

\section{Вміст і склад протеїнів найдовшого м'яза спини молодняку овець різного віку за умов інтенсивної відгодівлі}

\author{
В.В. Гавриляк ${ }^{1,2}$, П.В. Стапай ${ }^{2}$, В.М. Ткачук ${ }^{3}$ \\ ${ }^{1}$ Національний університет “Львівська політехніка”, м. Львів, Украӥна \\ ${ }^{2}$ Інститут біології тварин НААН, м. Львів, Украӥна \\ ${ }^{3}$ Інститут сільського господарства Карпатського регіону НААН, с. Оброшино, Пустомитівський район, \\ Львівська область, Україна
}

У статті наведено дані про вплив інтенсивної відгодівлі молодняку овещь на прирости маси тіла, хімічний і протеӥновий склад тканини найдовщого м'яза спини, біологічну та харчову иінність м'яса. Дослід провели на баранчиках асканійської тонкорунної породи таврійського типу. За методом аналогів було підібрано 12 голів новонароджених ягнят середньою масою тіла 4,58 кг, які утримувались на підсисі до 1,5-місячного віку. Після иього тварин перевели на інтенсивну відгодівлю. Встановлено, шьо за підсисний період маса ягнят в середньому становила 12,3 к2, абсолютний приріст - 7,8 к2, а середньодобовий - 172,1 2. 3а переведення тварин на інтенсивну відгодівлю середньодобові прирости маси тіла підвищилися до 215,0 г у 4-місячному віці і до 228,2 г - у 
5-місячному, або на 24,8 і 32,5\% більше порівняно з 1,5-місячними тваринами, які були на підсисі. У найдовщому м'язі спини баранчиків 4-місячного віку порівняно з 5-місячними встановлено менший вміст сухої речовини (на 1,08\%), загального жсиру (на 1,74\%) та більший вміст, загального і розчинного протеїну, відповідно, в 1,1 і 1,05 разу. 3 'ясовано, щчо у м'язовій тканині баранчиків 4- та 5-місячного віку найбільша частка розчинних протеїнів знаходилася в зоні рухливості альбумінів, менша - усіх фракцій глобулінів $i$ найменша - преальбумінів. Вищий вміст розчинних протеїнів у найдовшому м'язі спини баранчиків 4-місячного віку зумовлений за рахунок фракцій $\beta$ - $i$ ү-глобулінів, натомість у м'язі баранчиків 5-місячного віку є вищий вміст фракції преальбумунів і альбумінів. Отже, біологічна і харчова чінність м'яса баранчиків 4-місячного віку є кращою порівняно з 5-місячними тваринами.

Ключові слова: баранчики, годівля, найдовщий м'яз спини, протеӥни, хімічний склад.

\section{Вступ}

За біологічною цінністю м'ясо овець, особливо молода ягнятина, є ціннішим від баранини, оскільки у ньому міститься велика кількість біологічно активних речовин, зокрема пептидів, які беруть участь у метаболічних процесах організму. Якісні показники ягнятини значно вищі від м'яса дорослих овець.

Вміст протеїнів у органах і тканинах овець, з одного боку, характеризує їхні морфологічні, функціональні та метаболічні особливості, а 3 іншого - харчову цінність. Протеїни, які входять до складу м'язової тканини, характеризуються складною будовою, оскільки відрізняються за фізико-хімічними властивостями та біологічними функціями. Найбільший інтерес становлять протеїни саркоплазми, фібрил, ядер і сарколеми. До групи протеїнів саркоплазми, які є водорозчинними, належать міоглобін, глобулін $\mathrm{X}$, міоальбумін (Tarig et al., 2013).

Харчова і біологічна цінність саркоплазматичних протеїнів досить висока, що зумовлено наявністю в їх складі сульфурвмісних амінокислот, які характеризуються широким спектром біологічної дії в організмі людини (Pavlovskij and Pal'min, 1975).

Якість м'яса значною мірою залежить від віку тварин. У молодій баранині, порівняно з м'ясом дорослих тварин, міститься більше води, протеїну і менше жиру (Rennie et al., 1980; Borys, 2012). Дієтичні властивості м'яса молодої ягнятини зумовлені високим вмістом протеїнів та оптимальним співвідношенням між вмістом незамінних і замінних амінокислот (Rjadinskaja et al., 2012), а також вмістом інших цінних компонентів, зокрема вітамінів A, E, групи В та фосфоліпідів (Stapaj et al., 2018).

Відомо, що висока продуктивність овець зумовлена їхньою здатністю ефективно трансформувати поживні речовини корму у продукцію і тісно пов'язана 3 інтенсивним перебігом метаболічних процесів у організмі на всіх етапах - від використання поживних речовин у шлунково-кишковому тракті до біосинтезу протеїнів, ліпідів та інших життєво необхідних елементів.

При інтенсивному вирощуванні молодняку овець на відгодівлі обмінна енергія накопичується переважно у м'ясі та м'ясопродуктах (71-88\%), а у шкірі та волосяному покриві - всього 10-23\% (Sando et al., 2000). Отже, у цей період не варто використовувати раціони з високим вмістом протеїну, оскільки він використовується як енергетичний матеріал і тому бажаного ефекту не досягається. При збільшенні енергії у раціоні розпад органічної речовини зменшується, а перетравність протеїну практично не змінюється. При збільшенні рівня енергії з 7,29 до 7,94 мДж про- являється тенденція до зменшення перетравності БЕР i целюлози. Вважають, що для молодняку овець $\epsilon$ оптимальним раціон із вмістом $16 \%$ загального протеїну і рівнем енергії 7,70 мДж (Malenko, 1973; Sinclair, 2007).

Отже, у контексті викладеного виникає потреба у проведенні дослідження 3 вивчення біохімічного складу та біологічної цінності м'яса молодої баранини та ягнятини, одержаної від тварин, вирощених за умов інтенсивних технологій, з метою розроблення способів підвищення біоконверсії поживних речовин кормів у м'ясну продукцію.

\section{Матеріал і методи досліджень}

Дослід провели на баранчиках асканійської тонкорунної породи таврійського типу. За методом аналогів було підібрано 12 голів новонароджених ягнят середньою живою масою 4,58 кг, яких утримували на підсисі до 1,5-місячного віку. Після цього піддослідних тварин перевели на інтенсивну відгодівлю.

До складу раціону входили зерно ячменю, соняшникова макуха та сіно люцернове. За поживністю концентровані корми становили 65-70\%. Кількість перетравного протеїну становила 150 г на одну кормову одиницю. Годівля тварин здійснювалася двічі на добу з вільним доступом до води. Усі піддослідні тварини перебували за однакових умов утримання i догляду.

Об'єктом біохімічних досліджень була тканина найдовшого м'яза спини, зразки якої отримали після забою тварин 4- та 5-місячного віку, по три голови 3 кожної вікової групи.

Хімічний склад тканини найдовшого м'яза спини досліджували за загальновживаними методами (Vlizlo et al., 2012): суху масу - за різницею маси подрібненої тканини м'яза до і після висушування за температури $+105{ }^{\circ} \mathrm{C}$; загальний протеїн - визначенням вмісту азоту за К'єльдалем; жир - гравіметричним методом після екстракції ліпідів за методом Фолча (Folch et al., 1957), кількість золи визначали спалюванням наважки м'язової тканини у муфельній печі, а калорійність розрахунковим методом.

Екстракт водорозчинних протеїнів скелетного м'яза отримували при гомогенізації тканини в охолодженому фізіологічному розчині у співвідношення 1:5 (маса/об'єм) 3 подальшим центрифугуванням. Для електрофорезу використовували супернатант, що містив фракцію розчинних протеїнів найдовшого м'яза спини. Електрофорез у 7,5\% ПААГ проводили за стандартною методикою (Vlizlo et al., 2012) з використанням для аналізу програмного забезпечення TotalLab TL 120. Фракції розчинних протеїнів іденти- 
фікували відносно рухливості протеїнів сироватки крові.

Одержані цифрові дані опрацьовано статистично за допомогою Microsoft EXCEL $з$ використанням коефіцієнта Стьюдента. Результати вважали вірогідними, якщо $\mathrm{P}<0,05$.

\section{Результати та їх обговорення}

У результаті проведених досліджень встановлено, що у підсисний період, тривалість якого становила 1,5 місяці, маса тіла ягнят у середньому становила 12,3 кг, абсолютний приріст живої маси становив в середньому 7,8 кг, а середньодобовий - 172,1 г (табл. 1).

\section{Таблиця 1}

Маса тіла, середньодобові та абсолютні прирости баранчиків, кг $(\mathrm{M} \pm \mathrm{m}, \mathrm{n}=3)$

\begin{tabular}{lrcc}
\hline \multicolumn{1}{c}{ Вік ягнят } & Жива маса & Абсолютний приріст & Середньодобовий приріст \\
\hline Новонароджені & $4,58 \pm 0,23$ & - & - \\
1,5-місячні & $12,33 \pm 0,57$ & $7,75 \pm 0,48$ & $0,172 \pm 0,011$ \\
4-місячні & $28,5 \pm 0,67$ & $16,17 \pm 0,8$ & $0,215 \pm 0,011$ \\
5-місячні & $37,0 \pm 0,76$ & $25,33 \pm 0,93$ & $0,228 \pm 0,008$ \\
\hline
\end{tabular}

За переведення піддослідних тварин на інтенсивну відгодівлю середньодобові прирости маси тіла підвищилися до 215,0 г у 4-місячних тварин і до 228,2 г - у 5-місячних, або на 24,8 і 32,5\% більше порівняно 3 1,5-місячними тваринами на підсисі.

Отже, інтенсивність росту і розвитку молодняку овець із віком збільшується, зокрема, якщо до 4місячного віку середньодобові прирости становили 215,0 г, то у 5-місячних - 228,2 г, тобто на 13,2 г більше, або на $6,1 \%$.

Таким чином, отримані дані вказують на те, що за умов інтенсивної відгодівлі молодняк овець економічно вигідно реалізовувати у 5-місячному віці, хоча, як показали наші біохімічні дослідження найдовшого м'яза спини, біологічна і харчова цінність такого м'яса дещо знижується.

Так, у результаті досліджень хімічного складу найдовшого м'яза спини встановлено (табл. 2), що у м'язі тварин 4-місячного віку, порівняно 3 5місячними, є менший вміст сухої речовини (на 1,08\%) і загального жиру (на $1,74 \%$ ) та вищий вміст загального протеїну (на 1,78\%). Щоправда, усі ці різниці, окрім вмісту загального жиру, не є статистично вірогідними. I все ж, такі дані дають підставу вважати, що в біологічному плані м'ясо тварин молодшого віку є більш дієтичним і менш калорійним (на 137 ккал), що зумовлено низьким вмістом жиру. Як відомо, жирова тканина забезпечує високу калорійність, ніжність та ароматність м'яса, але надмірна кількість жиру у будь-якому м'ясі призводить до зменшення протеїну, а отже до погіршення його харчової цінності.

\section{Таблиця 2}

Хімічний склад найдовшого м'яза спини, \% (M $\pm \mathrm{m}$, $\mathrm{n}=3$ )

\begin{tabular}{|c|c|c|}
\hline \multirow{2}{*}{ Показник } & \multicolumn{2}{|c|}{ Вік тварин } \\
\hline & 4-місячні & 5-місячні \\
\hline Суха маса & $23,44 \pm 1,37$ & $24,52 \pm 0,50$ \\
\hline Протеїн & $18,91 \pm 0,74$ & $17,13 \pm 0,24$ \\
\hline Жир & $4,47 \pm 0,26$ & $6,21 \pm 0,50 *$ \\
\hline Зола & $1,18 \pm 3,38$ & $1,11 \pm 2,96$ \\
\hline $\begin{array}{l}\text { Енергетична цінність } \\
\text { м’яса, ккал/кг }\end{array}$ & 1145 & 1283 \\
\hline
\end{tabular}

Результати проведених досліджень показали, що у баранчиків 4-місячного віку вміст загального протеїну в м'язовій тканині є більший порівняно 3 тваринами 5-місячного віку. Подібна динаміка спостерігається і щодо розчинних протеїнів найдовшого м'яза спини, вміст яких коливається у межах 5\% (рис. 1).

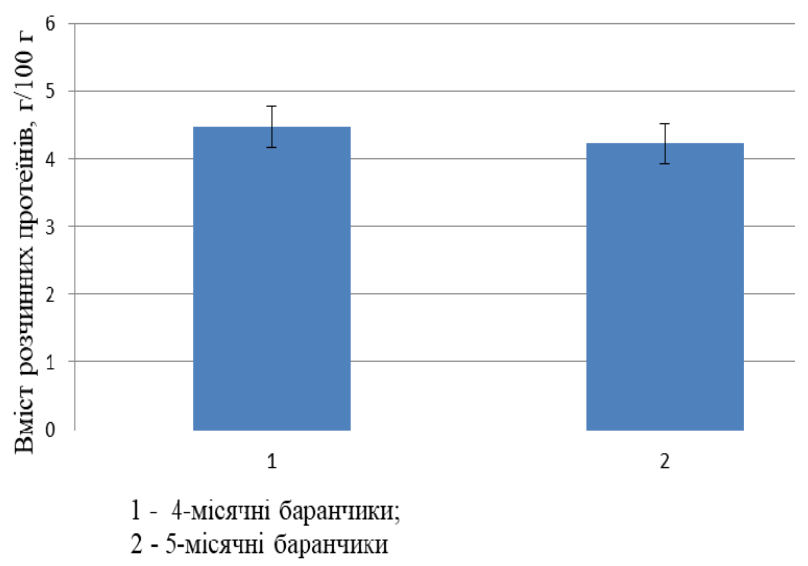

Рис. 1. Вміст розчинних протеїнів у найдовшому м'язі спини баранчиків, г/100 г, $\mathrm{M} \pm \mathrm{m}, \mathrm{n}=3$

При дослідженні в поліакриламідному гелі фракційного складу розчинних протеїнів скелетного м'яза баранчиків на електрофореграмах виявлено 10-11 смуг, які відповідно до фракцій протеїнів сироватки крові розділили на зони преальбумунів, альбумінів та глобулінів. 3'ясувалось, що у м'язовій тканині баранчиків 4- і 5-місячного віку найбільша частка розчинних протеїнів була в зоні рухливості альбумінів, менша - усіх фракцій глобулінів і найменша - преальбумінів.

Проведеними дослідженнями встановлено, що вміст преальбумінів у 1,55 раза більший у 5-місячних баранчиків. Подібна динаміка характерна також для альбумінів, натомість сумарна кількість глобулінів більша в баранчиків 4-місячного віку. Очевидно, що за рахунок саме глобулінових фракцій сумарний вміст розчинних протеїнів м'яза у 4-місячних ягнят є більшим. Варто відзначити, що всі фракції розчинних протеїнів м'язової тканини, які відповідають глобулінам сироватки крові, є гетерогенними. Як свідчать результати таблиці 3, вміст протеїнів, які відповіда- 
ють $\beta$-глобулінам сироватки крові, на 17,3 умовного пункту $(\mathrm{P}<0,05)$ більший у тварин 4-місячного віку. Подібна динаміка спостерігалася і щодо $\gamma$-глобулінів, тимчасом як вміст $\alpha$-фракції більший на 4,6\% у баранчиків 5-місячного віку.

\section{Таблиця 3}

Склад розчинних протеїнів найдовшого м'яза спини, $\%(\mathrm{M} \pm \mathrm{m}, \mathrm{n}=3)$

\begin{tabular}{ccc}
\hline \multirow{2}{*}{ Фракція } & \multicolumn{2}{c}{ Вік тварин } \\
\cline { 2 - 3 } & 4-місячні & 5-місячні \\
\hline Преальбуміни & $8,07 \pm 0,56$ & $12,47 \pm 0,40^{*}$ \\
Альбумін & $31,06 \pm 3,31$ & $34,55 \pm 0,77$ \\
Глобуліни: & & \\
$\alpha$ & $22,38 \pm 0,78$ & $23,40 \pm 1,50$ \\
$\beta$ & $22,23 \pm 1,14$ & $18,38 \pm 0,57^{*}$ \\
$\gamma$ & $15,65 \pm 2,55$ & $11,19 \pm 0,44$ \\
\hline
\end{tabular}

Отже, підсумовуючи результати досліджень розчинних протеїнів найдовшого м'яза спини молодняку овець, можна констатувати, що у тварин старшого віку, тобто 5-місячних, у скелетних м'язах переважають фракції пре-і альбумінів, які у сумі складають 47\% проти 39,1\% у 4-місячних. Натомість фракції $\alpha-$, $\beta$ - і $\gamma$-глобулінів у них зменшується до $52,9 \%$ проти $60,3 \%$ у 4-місячних. Таким чином, зміни співвідношення окремих фракцій розчинних протеїнів у тканині найдовшого м'яза спини можуть свідчити про перерозподіл між фракціями саркоплазматичних протеїнів, до яких відносяться міоген, глобулін $\alpha$, міоальбумін і міоглобіни. Ця група протеїнів, як відомо, має високу харчову та біологічну цінністю, зумовлену наявністю у їхньому складі сульфурвмісних амінокислот, які характеризуються широким спектром біологічної дії в організмі людини. Зокрема, на фракцію міогену припадає приблизно двадцять відсотків всіх протеїнів м'язової тканини, який за фізико-хімічними властивостями подібний до альбумінів. У складі цієї фракції є численні ферменти які виконують функції, пов'язані із перетворенням вуглеводів та інших сполук.

\section{Висновки}

1. За умов інтенсивної відгодівлі середньодобові прирости маси тіла молодняку овець є вищими порівняно 3 підсисним періодом на 24,7\% у 4-місячному віці та на 36,7\% - у 5-місячному.

2. У найдовшому м'язі спини баранчиків 5-місячного віку, порівняно з 4-місячними, є вищий вміст сухої речовини і загального жиру та менший загального протеїну.

3. Вищий вміст розчинних протеїнів у найдовшому м'язі спини баранчиків 4-місячного віку зумовлений фракціями $\beta$ - і $\gamma$-глобулінів, натомість у м'язі баранчиків 5-місячного віку є вищий вміст фракцій преальбумінів та альбумінів відповідно на 54,5 і 11,2 ум. пункту.
4. 3 біологічної і харчової оцінки м'ясо баранчиків 4-місячного віку, порівняно з 5-місячними, є ціннішим, проте економічно доцільнішою $є$ реалізація їх на забій у старшому віці, тобто у 5-місячному.

Перспективи подальших досліджень. Подальші дослідження доцільно провести на молодняку овець 9-місячного віку.

\section{References}

Borys, B. (2012). Lipid profile of intramuscular fat in lamb meat. Animal Science Papers and Reports, 30(1), 45-56. https://www.researchgate.net/publication/ 266000346/download.

Folch, J., Lees, M., \& Stanley, G.H.S. (1957). A simple method for the isolation and purification of total lipides from animal tissues. J. Biol. Chem., 226(1), 497-450. http://www.jbc.org/content/226/1/497.full.pdf.

Malenko, G.P. (1973). Methodical guidelines for the study of lipid metabolism in farm animals, Borovsk, 87-89 (in Russian).

Pavlovskij, P.E., \& Pal'min, V.V. (1975). Biohimija mjasa. M.: Pishhevaja promyshlennost' (in Russian).

Rennie, M.S., Edvards, R.H., \& Davies, T.M. (1980). Protein and amino acid during and after exercise. Biochem. Sci.Trans, 8, 1-36. doi: 10.1146/annurev.nutr.20.1.457.

Rjadinskaja, N.I., Ikonnikov, O.L., \& Mezencev, S.V. (2012). Himicheskij i aminokislotnyj sostav mjasa ovec prikatunskogo tipa gornoaltajskoj porody $\mathrm{v}$ rannem postnatal'nom ontogeneze. Vestnik Altajskogo gosudarstvennogo agrarnogo universiteta. Barnaul, 10(96), 92-95. http://www.asau.ru/vestnik/2012/10/ Breeding_Ryadinskaya.pdf (in Russian).

Sando, C., Enser, M.E., Campo, M.M., Nute, G.R., Maria, G., Sierra, I., \& Wood, I.D. (2000). Fatty acid composition and sensory characteristics of lamb carcasses from Britain and Spain. Meat Science, 54, 339-346. doi: 10.1016/S0309-1740(99)00108-4.

Sinclair, L.L. (2007). Nutritional manipulation of the fatty acid composition of sheep meat: a review. Aqr. Sci., 145(5), 419-434. doi: 10.1017/S0021859607007186.

Tarig, M.M., Eyduran, E., Rafeeq, M., Waheed, A., Arif Awan, M., Shafee, M., Rasheed, N., \& Mehmood, K. (2013). Influence of Slaughtering Age on Chemical Composition of Mengali Sheep Meat at Quetta. Pakistan J. Zool., 45(1), 235-239. http://zsp.com.pk/ pdf45/235-239\%20_31_\%20PJZ-1042-12\%205-1$13 \% 20$ final $\% 20$ revised $\% 20$ tariq $\% 20 \mathrm{~m} \% 20$ r.pdf.

Vlizlo, V.V., Fedoruk, R.S., \& Ratych, I.B. (2012). Laboratory methods of investigation in biology, stockbreeding and veterinary. Lviv (in Ukrainian).

Stapaj, P.V., Paranjak, N.M., Tkachuk, V.M., \& Stahiv, N.P. (2018). Vmist i sklad lipidiv najdovshogo m'jaza spyny molodnjaku ovec' riznogo viku za umov intensyvnoi' vidgodivli. Biologija tvaryn, 20(2), 71-76. doi: 10.15407/animbiol20.02.071 (in Ukrainian). 